\title{
High diluted molecules and gene expression
}

\section{Salvatore Chirumbolo*}

University Laboratories for Medical Research (LURM)-Medicine D, Department of Medicine, University of Verona, Verona, Italy

${ }^{*}$ Correspondence: salvatore.chirumbolo@univr.it

Edited by:

Ruiwen Zhang, Texas Tech University Health Sciences Center, USA

Reviewed by:

He-Hui Xie, Second Military Medical University, China

Judith Ann Smith, UT Health Medical School of Houston, USA

Keywords: gelsemine, Gelsemium, Gelsemium sempervirens, homeopathy, biases, microarray gene expression

\section{A commentary on}

Extreme sensitivity of gene expression in human SH-SY5Y neurocytes to ultra-low doses of Gelsemium sempervirens

by Marzotto, M., Olioso, D., Brizzi, M., Tononi, P., Cristofoletti, M., and Bellavite, P. (2014). BMC Complement. Altern. Med. 14:104. doi: 10.1186/1472-6882-14-104

Two recently published papers reported that water/ethanol dilutions of Gelsemium sempervirens Ait. extracts could modify gene expression on in vitro human neuronal cells (Marzotto et al., 2014; Olioso et al., 2014). Both papers were performed with the purpose to demonstrate cellular activity of $G$. sempervirens dilutions, on suited standardized cultures, and confirm the behavioral evidence previously reported elsewhere (Magnani et al., 2010). The authors used two models for their experimental setting, namely $\mathrm{SH}$ SY5Y and CCL-127 or IMR32 neuroblastoma cell lines (Marzotto et al., 2014; Olioso et al., 2014). After an oligonucleotide microarray, the authors selected less than 10 genes for RT-PCR to be significantly expressed following Gelsemium treatment (Marzotto et al., 2014; Olioso et al., 2014). However, using human neuronal cell line to elucidate results obtained with mouse models appears quite disputable. The search for an involvement of neural genes related to anxiety/depression or mood disorders is biased by the expression of human genes having no orthologs/homologs in mice, where the authors reported evidence about Gelsemium action on behavioral tests in animal anxiety models. For example, the gene baculoviral IAP repeat containing 8
(BIRC 8) has no homologs in mice (only ortholog genes in Pan troglodytes), olfactory gene OR4X1 is not expressed (absent) in mouse, gene C1ORF167 appears to have a non-characterized ortholog gene LOC102634746 in mouse, certainly not matching the research purpose to relate olfactory gene to the behavioral test. Furthermore, some genes indicated to be downregulated by Gelsemium $2 c$, should not be expressed by neuronal cells (e.g. CD163, MPO, C8B, LST1, TREM2, notoriously expressed in immune cell). Both papers (Marzotto et al., 2014; Olioso et al., 2014) represent two interesting reports about gene expression microarray in homeopathy or ethnopharmacology, yet they deserves many comments about experimental setting and performance.

Preparations of herbal dilutions was carried out starting from a G. sempervirens "mother tincture" from Boiron and a gelsemine content of $6.5 \times 10^{-4} \mathrm{M}$ was reported (Marzotto et al., 2014). Yet concentration of gelsemine was not assessed, as it was solely calculated on previous spectrometry investigations (Magnani et al., 2010) and new preparations, from ethanol draw extracts, were not further quantified by analytical chemistry. Although the authors reported UV-Vis spectra of $G$. sempervirens, which showed a peak at $250 \mathrm{~nm}$ caused by contaminating millimolar ethanol in Gelsemium $2 c$, they did not calculate any active principle dose in the tested solutions (Marzotto et al., 2014). Therefore, the authors tested a complex mixture of G. sempervirens extract, containing at least about $0.154 \mathrm{mM} \mathrm{EtOH}$ at $2 \mathrm{c}$, if dilutions were conducted exactly, yet an alcoholic draw extract whose active principles were not identified for the investigation setting (Jin et al., 2014). The theoretical ethanol concentration evaluable by reading Marzotto's paper might reach actually $50 \mathrm{mM}$ at Gelsemium 2c (Marzotto et al., 2014). A sub-millimolar dose of EtOH, close to $0.2 \mathrm{mM}$ ethanol, is able to affect cell activity as BrdU incorporation, DNA fragmentation increase and LDH release, although data refer to HepG2 cell line at $24 \mathrm{~h}$ incubation with EtOH (Castañeda and Kinne, 2000). A strong apoptotic induction was related to ethanol doses as low as $100 \mathrm{mM}$ for $24 \mathrm{~h}$ (Do et al., 2013) but $1.0 \mathrm{mM} \mathrm{EtOH}$ induce latent apoptosis in a cell line system and modifies expression of genes not necessarily involved in alcohol metabolism (Castaneda et al., 2007; Kupfer et al., 2013). Concentration of $\mathrm{EtOH}$, set at $30 \% \mathrm{v} / \mathrm{v}$, faded out to $0.003 \%$ in tested dilutions but the authors did not clarify how much for each centesimal dilution in the Methods section; the reader might trust the supposition that each centesimal dilution has about $50 \mathrm{mM}$ EtOH. One paper reported that G. sempervirens 2c was prepared by diluting 100 times into simple distilled water a MT from Boiron (30 to $0.3 \%$ ethanol) to reach $1 \mathrm{c}$ and further 100 times ( 0.3 to $0.03 \%$ ethanol) to $2 \mathrm{c}$ (Marzotto et al., 2014). This may correspond to an ethanol concentration of about $50 \mathrm{mM}$ at $0.3 \%$ EtOH. In Marzotto et al., more than $87 \%$ genes were downregulated, suggesting probably for a noxious action on cell function (Marzotto et al., 2014). Furthermore, the authors did not specify whether G. sempervirens preparations and serially diluted 30\% alcohol/water solutions, were made under a laminar flow hood or provided sterile disposable plastic 
ware. This should lead to the conclusion that EtOH/water dilutions may not be endotoxin-free. To prevent bacterial contamination of the tested solutions, a Limulus amebocyte lysate test (LAL test) should be performed. Lipopolysaccharide can activate neuroblastoma genes (Nitta et al., 1994) and, if present as contaminant in herbal medicine, may affect gene microarray (Chang et al., 2012).

Finally the authors should have selected an array reporting a panoply of genes involved in the molecular mechanism they discussed about behavioral test (Magnani et al., 2010). Gene array profile of expression following $24 \mathrm{~h}$ incubation with G. sempervirens 2c, showed downregulation of 49 genes, namely $87.5 \%$ gene array. Many gene products, listed in the expression profile of 56 genes array, such as LOC154872, KIAA0825, LOC150763, C1orf167, have not been identified (e.g. LOC644065) or are long intergenic non-coding protein RNA (C21orf24). Some genes are not reported/coded in the human genome, for example genes affected by Gelsemium 2c, such as DDl1, are bacterial genes, notoriously absent/non expressed in Homo sapiens: probably is a misprint (delta-like 1 (DLL1) instead of Dalanine-D-alanine ligase (DDl1) (Olioso et al., 2014), while other are exclusively expressed in humans, such as OR5C1 (olfactory receptor 5C1) while mouse has an olfactory receptor 368 gene on chromosome 2. Both papers did not show any exciting and significant action by very high diluted G. sempervirens solutions, contrarily to the conclusive remarks reported elsewhere (Magnani et al., 2010). The progression of the molecular assay revolution currently relies on the ability to efficiently and accurately offer multiplex detection and characterization for a variety of genes. Microarray analysis has the capability to offer robust multiplex detection but has just started to enter the research in high diluted substances. Although the use of microarrays to generate gene expression data has become routine, applications pertinent to high dilution pharmacology continue to rapidly expand. Further insights are needed to fix biases and misinterpretations leading to misunderstanding the effect of $G$. sempervirens raw extract respect to single active components.

\section{REFERENCES}

Castañeda, F., and Kinne, R. K. (2000). Cytotoxicity of millimolar concentrations of ethanol on HepG2 human tumor cell line compared to normal rat hepatocytes in vitro. J. Cancer Res. Clin. Oncol. 126, 503-510. doi: 10.1007/s0043200 00119

Castaneda, F., Steiner, S. R., and Jung, K. (2007). Functional genomics analysis of low concentration of ethanol in human hepatocellular carcinoma (HepG2) cells. Role of genes involved in transcriptional and translational processes. Int. J. Med. Sci. 4, 28-35. doi: 10.7150/ ijms. 4.28

Chang, H. T., Huang, C. Y., Chen, C. R., Chang, C. W., Shu, W. Y., Chiang, C. S., et al. (2012). "Gene expression reproducibility analysis for the treatment of two different batches of Cordyceps Sinensis by loop-design microarray experiments," in Proceedings of the World Congress on Engineering and Computer Science 2012, WCECS 2012, Vol II, (San Francisco, CA).

Do, H., Park, H. J., Sohn, E. H., Kim, B. O., Um, S. H., Kwak, J. H., et al. (2013). Ethanol induces cell cycle arrest and triggers apoptosis via Sp1dependent p75NTR expression in human neuroblastoma cells. Cell Biol. Toxicol. 29, 365-380. doi: 10.1007/s10565-013-9260-3

Jin, G. L., Su, Y. P., Liu, M., Xu, Y., Yang, J., Liao, K. J., et al. (2014). Medicinal plants of the genus Gelsemium (Gelsemiaceae, Gentianales)-a review of their phytochemistry, pharmacology, toxicology and traditional use. J. Ethnopharmacol. 152, 33-52. doi: 10.1016/j.jep.2014.01.003

Kupfer, D. M., White, V. L., Strayer, D. L., Crouch, D. J., and Burian, D. (2013). Microarray characterization of gene expression changes in blood during acute ethanol exposure. BMC Med. Genomics. 6:26. doi: 10.1186/1755-8794-6-26

Magnani, P., Conforti, A., Zanolin, E., Marzotto, M., and Bellavite, P. (2010). Dose-effect study of Gelsemium sempervirens in high dilutions on anxiety-related responses in mice. Psychopharmacology (Berl.) 210, 533-545. doi: 10.1007/s00213-010-1855-2

Marzotto, M., Olioso, D., Brizzi, M., Tononi, P., Cristofoletti, M., and Bellavite, P. (2014). Extreme sensitivity of gene expression in human SH-SY5Y neurocytes to ultra-low doses of Gelsemium sempervirens. BMC Complement. Altern. Med. 14:104. doi: 10.1186/1472-6882-14-104

Nitta, T., Ebato, M., Sato, K., and Okumura, K. (1994) Expression of tumour necrosis factor-alpha, -beta and interferon-gamma genes within human neuroglial tumour cells and brain specimens. Cytokine 6, 171-180. doi: 10.1016/1043-4666(94)90039-6

Olioso, D., Marzotto, M., Moratti, E., Brizzi, M., and Bellavite, P. (2014). Effects of Gelsemium sempervirens L. on pathway-focused gene expression profiling in neuronal cells. J. Ethnopharmacol. 153, 535-539. doi: 10.1016/j.jep.2014.02.048

Conflict of Interest Statement: The author declares that the research was conducted in the absence of any commercial or financial relationships that could be construed as a potential conflict of interest.

Received: 26 June 2014; accepted: 19 July 2014; published online: 14 August 2014.

Citation: Chirumbolo S (2014) High diluted molecules and gene expression. Front. Pharmacol. 5:183. doi: 10.3389/fphar.2014.00183

This article was submitted to Ethnopharmacology, a section of the journal Frontiers in Pharmacology.

Copyright (c) 2014 Chirumbolo. This is an openaccess article distributed under the terms of the Creative Commons Attribution License (CC BY). The use, distribution or reproduction in other forums is permitted, provided the original author(s) or licensor are credited and that the original publication in this journal is cited, in accordance with accepted academic practice. No use, distribution or reproduction is permitted which does not comply with these terms. 